\title{
Mountain-derived versus shelf-based glaciations on the western Taymyr Peninsula, Siberia
}

\author{
Christian Hjort ${ }^{1}$ \& Svend Funder ${ }^{2}$ \\ 1 Quaternary Sciences, Lund University, GeoCenter II, Sölvegatan 12, SE-223 62 Lund, Sweden \\ 2 Natural History Museum, University of Copenhagen, Øster Voldgade 5-7, DK-1350 Copenhagen K, Denmark
}

\section{Keywords}

Siberian geology; glacial inception; glacial history.

\section{Correspondence}

C. Hjort, Quaternary Sciences, Lund University, GeoCenter II, Sölvegatan 12, SE-223 62 Lund, Sweden. E-mail:

christian.hjort@geol.lu.se

doi:10.1111/j.1751-8369.2008.00068.x

\begin{abstract}
The early Russian researchers working in central Siberia seem to have preferred scenarios in which glaciations, in accordance with the classical glaciological concept, originated in the mountains. However, during the last 30 years or so the interest in the glacial history of the region has concentrated on ice sheets spreading from the Kara Sea shelf. There, they could have originated from ice caps formed on areas that, for eustatic reasons, became dry land during global glacial maximum periods, or from grounded ice shelves. Such ice sheets have been shown to repeatedly inundate much of the Taymyr Peninsula from the north-west. However, work on westernmost Taymyr has now also documented glaciations coming from inland. On at least two occasions, with the latest one dated to the Saale glaciation (marine isotope stage 6 [MIS 6]), warm-based, bedrock-sculpturing glaciers originating in the Byrranga Mountains, and in the hills west of the range, expanded westwards, and at least once did such glaciers, after moving $50-60 \mathrm{~km}$ or more over the present land areas, cross today's Kara Sea coastline. The last major glaciation affecting southwestern Taymyr did, however, come from the Kara Sea shelf. According to optically stimulated luminescence dates, this was during the Early or Middle Weichselian (MIS 5 or 4), and was most probably not later than 70 Kya. South-western Taymyr was not extensively glaciated during the last global glacial maximum ca. $20 \mathrm{Kya}$, although local cold-based ice caps may have existed.
\end{abstract}

The idea that during periods of cooling glacial inceptions usually start in the mountains, from where the surrounding lowlands may gradually be inundated by the ice, has been central to the ice-age theory since it originated in Switzerland long ago (e.g., Agassiz 1840). That this concept should also be valid for Siberia, was suggested, for example, by glacial history pioneers such as Urvantsev (1931, 1935), Saks (1953) and Strelkov (1965). However, as early as 1930 Obruchev briefly discussed a glaciation centred on the Kara Sea shelf (Obruchev 1930), and later this concept of Kara Sea ice sheets inundating the northwestern and central parts of the Taymyr Peninsula has played a rather dominant role in the literature (Astakhov 1976; Grosswald 1980, 1998; Kind \& Leonov 1982; Isayeva 1984), and has been confirmed in more recent publications (Möller et al. 1999; Alexanderson et al. 2001; Alexanderson et al. 2002; Hjort et al. 2004; Svendsen et al. 2004; Astakhov \& Mangerud 2005). However, results from fieldwork in 2002 along the Gusinaya and Nizmennaya rivers on westernmost Taymyr show that on at least two occasions the glaciers expanded from the inland regions, in this particular case from the western parts of the Byrranga Mountains (here up to 500-600-m high) towards the Kara Sea basin.

The fieldwork was carried out in July and August 2002 (Hjort et al. 2003) as part of the Quaternary Environments of the Eurasian North (QUEEN) programme. It was based at two camps, one by the Gusinaya River $\left(75^{\circ} 01^{\prime} \mathrm{N}\right.$, $\left.88^{\circ} 10^{\prime} \mathrm{E}\right)$ and the other by the Nizmennaya River $\left(75^{\circ} 40^{\prime} \mathrm{N}, 92^{\circ} 45^{\prime} \mathrm{E}\right)$, both situated ca. $10 \mathrm{~km}$ from the Kara Sea coast in the area between Middendorf Bay and the Michaylova Peninsula (Fig. 1).

According to Kind $\delta$ Leonov (1982) and Isayeva (1984), mainly based on radar satellite and aerial photographic mapping, these are areas that should be inside or on the southernmost part of the North Taymyr 

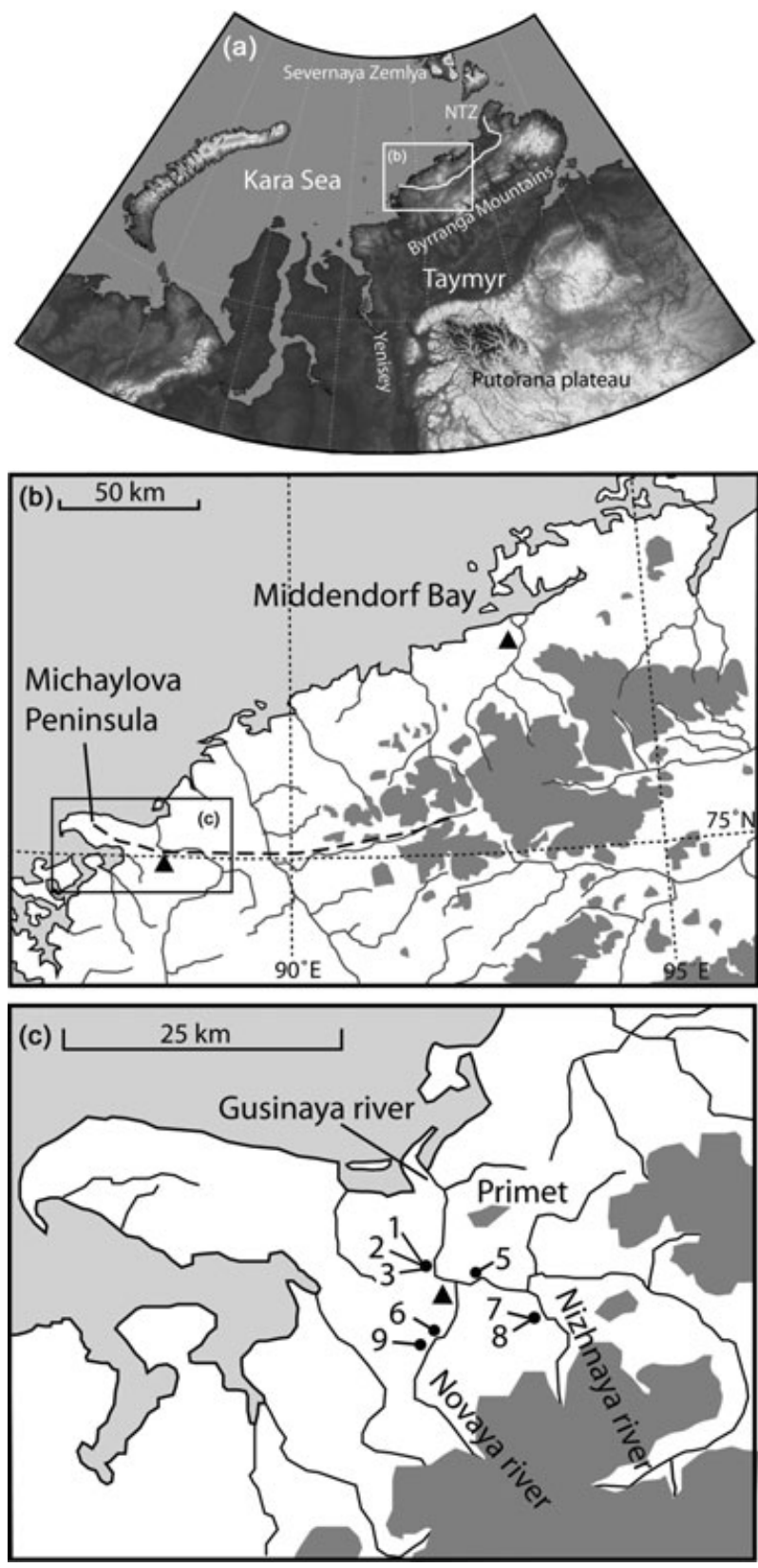

Fig. 1 (a) The Kara Sea and Taymyr Peninsula region in Arctic Russia, showing the original delimitation of the North Taymyr ice-marginal zone (NTZ). (b) Fieldwork area on western Taymyr 2002, with the camps at Gusinaya River (to the south) and the Nizmennaya River (north) indicated by black triangles. Shaded areas are more than $300 \mathrm{~m}$ a.s.l. The dashed line indicates the earlier proposed delimitation of the NTZ in the area studied. (c) Working area around the Gusinaya River, with sampled localities numbered as in Table 1. Areas more than $100 \mathrm{~m}$ a.s.I. are shaded.

ice-marginal zone (NTZ; see Fig. 1), and would thus have been overridden by an ice sheet in Late Weichselian/ Last Glacial Maximum (LGM) times. However, in the Gusinaya area we found no signs of any large-scale ice- marginal features, such as those observed along the NTZ further north (Alexanderson et al. 2001; Alexanderson et al. 2002), although this is where the ice-marginal zone should reach the coast, according to the aforementioned mapping. The NTZ that was mapped here earlier, from aerial photographs and satellite images, seems to consist mainly of bedrock structures, which are partly related to a local boundary between granites and clastic rocks (Bezzubcev et al. 1986; Malič 1999; Pease \& Persson 2006). That it is not a glacial boundary was also concluded by Antonov et al. (2002).

The highest marine limit in the area we studied is at ca. $45 \mathrm{~m}$ a.s.l., by the Gusinaya River. It is documented both by erosional scarps in bedrock and till, and by the upper surfaces of marine foreshore sediments, which neither have till cover nor show other signs of glacial overriding. It is radiocarbon dated to $>40$ Kya from marine shells (Astarte borealis, Mya truncata, Hiatella arctica; Sample 1, Table 1) collected in these sediments. The sediments as such were dated using optically stimulated luminescence (OSL) to between 105 and 86 Kya (Samples 2 and 3, Table 1; all of the OSL dates used here were originally published and methodologically discussed by Thomas et al. 2006). The altitude of the marine limit could not be ascertained in the Nizmennaya area, but its minimum age there is indicated by a radiocarbon date of $>40 \mathrm{Kya}$ (Sample 4, Table 1) from paired shells of $A$. borealis with their periostracum intact, which were collected from a silt immediately underlying Holocene non-glacial fluvial sediments.

\section{The Gusinaya area}

Bedrock exposures along the central Gusinaya River, especially upstream from its confluence with the Novaya River, are glacially sculptured, with both stoss- and leeside morphology and striations. They are usually quite weathered, indicating a not very recent deglaciation. The general sculpture and striations show that the ice came from inland, from the north-east/south-east sector, but it is also very evident that the ice flow here followed the valley, and thus the directions of the striations vary from site to site along the winding river.

A more comprehensive indication of the general direction of this ice expansion from the inland is given by Primet Hill (ca. 150-m high), some kilometres north of the Gusinaya River (Fig. 1). This gabbro bedrock hill, described by Pease \& Persson (2006), has a distinct, roughly east-west stoss- and lee-side morphology (Fig. 2a), with up to 10-m high steep cliffs on its lee-side, and an elongated till-covered slope with many erratic boulders on the stoss side. According to the glacial sculpture, and especially to some rather well-preserved glacial 
Table 1 Optically stimulated luminescence (OSL) and accelerator mass spectrometry (AMS) ${ }^{14} \mathrm{C}$ dates, with sample numbers (sites) according to Fig. 1c. Sample 4 is from the Nizmennaya area. Details about the OSL dates are described by Thomas et al. (2006).

\begin{tabular}{llllcc}
\hline Sample no. & Dating method & Lab. no. & Material & m a.s.l. & Age (Kya) \\
\hline 1 & AMS ${ }^{14} \mathrm{C}$ & LuA-5470 & Bivalve shell (Astarte borealis) & 40 & $>40$ \\
2 & OSL & R-021034 & Foreshore sand & 35 & $105 \pm 8$ \\
3 & OSL & R-021035 & Foreshore sand & 30 & $86 \pm 7$ \\
4 & AMS ${ }^{14} \mathrm{C}$ & LuA-5479 & Bivalve shell (Astarte borealis) & 0 & $>40$ \\
5 & OSL & R-021036 & Glaciolacustrine sand & 18 & $153 \pm 14$ \\
6 & OSL & R-021033 & Kame sand & 35 & $152 \pm 9$ \\
7 & OSL & R-021038 & Kame sand & 10 & $129 \pm 9$ \\
8 & OSL & R-021037 & Kame sand & 12 & $123 \pm 10$ \\
9 & OSL & R-021032 & Kame gravel & 30 & $71 \pm 5$ \\
\hline
\end{tabular}
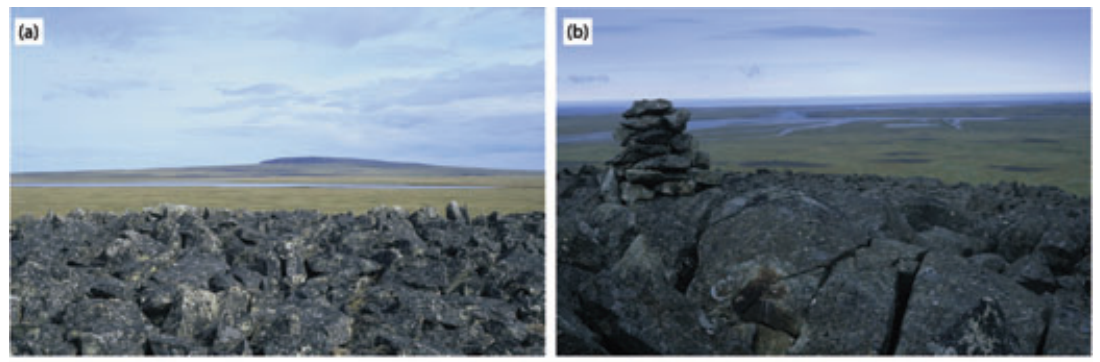

(c)

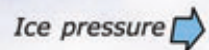

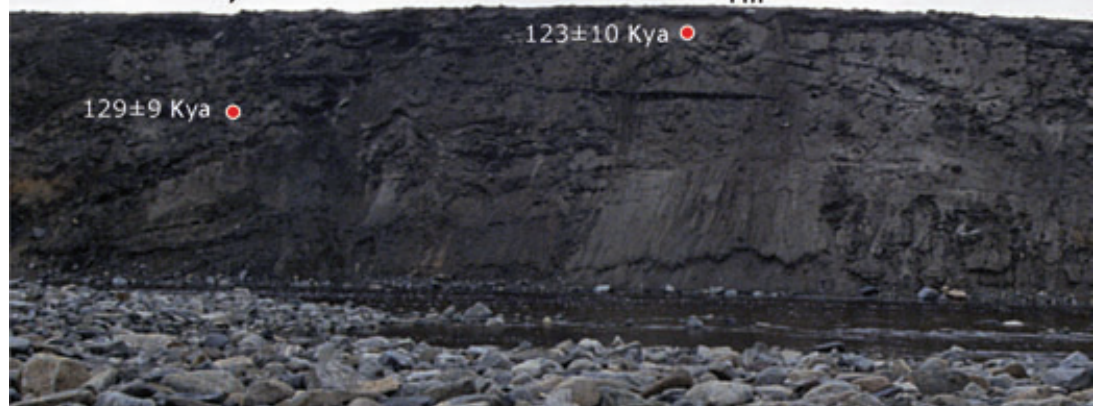

(d)

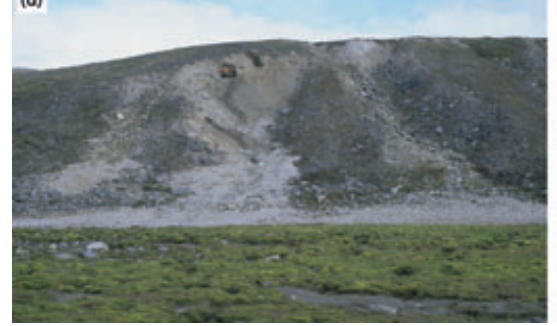

(e)

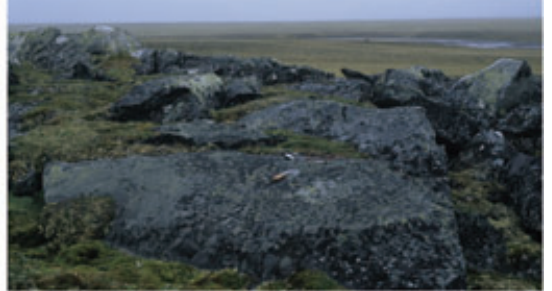

Fig. 2 (a) Primet Hill (ca. $150 \mathrm{~m}$ high; see Fig. 1c), with its glacial stoss- and lee-side topography from roughly east to west. (b) Glacially sculptured rocks at the top of Primet Hill, with striations from ca. $140^{\circ}$, indicating the inland origin of the last warm-based glacier that overrode the hill. (c) Kame section by the Nizhdated optically stimulated luminescenceby a thin till, deposited by ice that moved from inland towards the Kara Sea. (d) Sediment section along the north side of the Gusinaya River, corresponding to site 5 in Fig. 1c, and with the sediment log shown in Fig. 3. (e) Glacially sculptured rock near the lower Nizmennaya River, with striations from ca. $290^{\circ}$ documenting an ice movement from the Kara Sea basin.

striations near the hill-top (Fig. 2b), the last warm-based, sculpturing ice that affected this hill moved from ca. $140^{\circ}$, i.e., from the westernmost part of the Byrranga Mountains, and expanded almost perpendicularly towards the present coastline.

The glacially sculptured rocks along the Gusinaya River are sometimes overlain, and are thus postdated by a sequence of glaciolacustrine and fluvial sediments
(Fig. 2d). These sediments (Fig. 3), with out-sized clasts (dropstones?) in sand followed by a coarse gravel bed at the top, possibly indicating an approaching ice, are covered by a ca. 2-m thick diamicton. This diamicton consists of boulders, gravel and sand in a silty matrix, is weakly stratified and contains fragments of marine shells, especially A. borealis. The diamicton is interpreted as a till, and the silt, the shell fragments and the fabric 


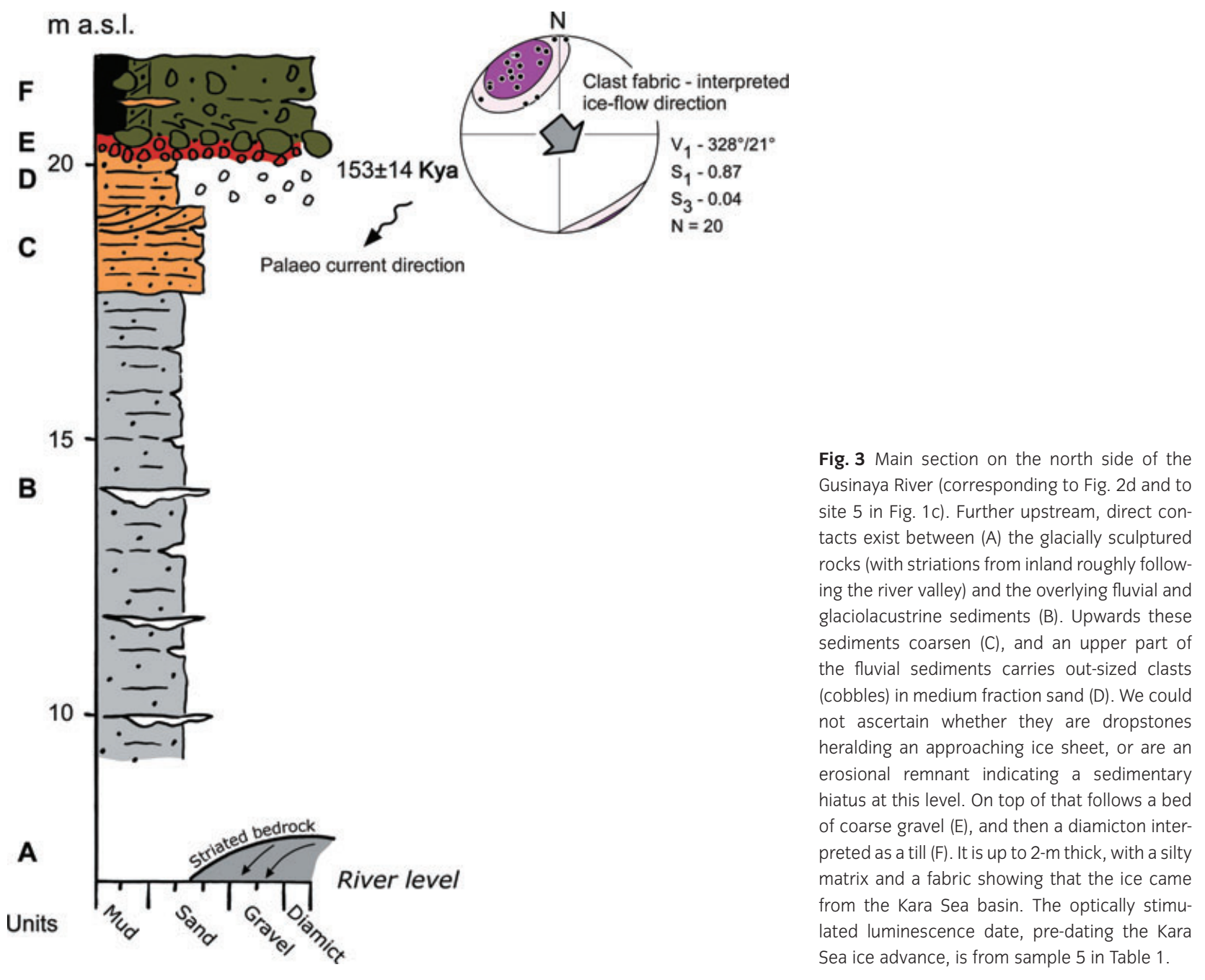

from ca. $330^{\circ}$ indicate that it was laid down by ice coming from the Kara Sea. The upper parts of the glaciolacustrine and fluvial sediment pile have been OSL dated to ca. 150 Kya (Samples 5 and 6, Table 1), indicating that the inland-derived, warm-based glaciation sculpturing the underlying rocks was of Early Saalian age (marine isotope stage 6, MIS 6; local terminology Muruktin or Taz), or older.

A stratigraphically younger section further upstream along the Gusinaya River indicates that a Late Saalian ice movement from inland towards the coast also occurred there. On the western side of the small Nizhnaya River, a southern tributary to the Gusinaya River, about $500 \mathrm{~m}$ upstream from the Nizhnaya-Gusinaya confluence, a ca. 15-m-high section has been cut through a kame (Fig. 2c). The kame sand and gravel were deposited, overridden and tectonized by a glacier moving coastwards from ca. 130-145', which also left a thin (ca. $0.1 \mathrm{~m}$ ) till draping the top of the hill. We interpret this sequence as reflecting an ice-marginal environment, with the tectonism and till marking the last spasm of a wasting ice sheet centered over the land. The kame sediments are OSL dated to ca. 125 Kya (Samples 7 and 8, Table 1). Considering that OSL dates have been shown to often underestimate Eemian ages (Murray \& Funder 2003), we find it most likely that this sequence marks the final melting of a Saalian ice sheet in this area.

The age of the aforementioned Kara Sea till, which overlies the sediment sections along the Gusinaya River further downstream (e.g., Fig. 3) is, however, rather uncertain. There may be a sedimentary hiatus associated with the cobble and gravel zone just below it, and if this is the case it could be as young as ca. $70 \mathrm{Ky}$, which is the OSL age of sandy kame sediments deposited from the north, $2 \mathrm{~km}$ south of our camp on the Gusinaya River (Sample 9, Table 1). This would then be of roughly the same age as the youngest Kara Sea ice sheet that reached southwards to the mouth of the Yenisey River (Astakhov 
\& Mangerud 2005, 2007), and as the last major Kara Sea ice terminating along the central parts of the NTZ (Alexanderson et al. 2001; Alexanderson et al. 2002; Hjort et al. 2004).

\section{The Nizmennaya area}

In contrast to the many sections cut by rivers and streams into glacial, glaciofluvial and glaciolacustrine deposits in the Gusinaya area, the Nizmennaya area is poor in such features. Some till-covered areas and glacially transported boulders of mostly local origin are all one encounters in this respect. Most rock exposures on the flat tundra here are extensively weathered, often with tors. However, some rocks ca. $5 \mathrm{~km}$ upstream from the camp still retain a weak stoss- and lee-side morphology, indicating ice movement from inland, from ca. $160^{\circ}$.

A small rock exposure halfway between our camp (Fig. 1) and the sea has a distinct stoss- and lee-side sculpture, with striations made by ice coming from ca. $290^{\circ}$, from the Kara Sea basin (Fig. 2e).

\section{Discussion and conclusions}

The conclusion from these observations, especially from along the Gusinaya River, is that on two documented occasions glaciers have expanded north-westwards from the western parts of the Byrranga Mountains and adjacent hills, towards the present coast of the Kara Sea. The well-developed, warm-based ice-indicating sculpture on top of the Primet Hill suggests that the ice was at least thick enough to reach the present coast, only $5 \mathrm{~km}$ away, and perhaps well beyond it. The distance from the suggested inception area in the western Byrrangas to our sites on the Gusinaya is at least $50-60 \mathrm{~km}$, whereas the distance from some hills closer to the sculptured rocks by the Nizmennaya River is only ca. $10 \mathrm{~km}$.

Thus, although the glacial morphology and the glacial deposits on western Taymyr are to a large extent derived from ice coming out of the Kara Sea basin (Grosswald 1980; Isayeva 1984; Alexanderson et al. 2001; Hjort et al. 2004; Svendsen et al. 2004), we can now document that glaciers have also expanded extensively outwards from the local highlands. As initially noted, glaciologically speaking, this should be no surprise, and these glacial expansions may parallel those from the Putorana highlands, east of the Yenisey River and just south of the Taymyr Peninsula (Isayeva 1984; Hahne \& Melles 1997; Astakhov \& Mangerud 2007). This inland inception pattern, at least partly with warm-based glaciers, is similar to a recently published scenario from the Severnaya Zemlya islands, some $400 \mathrm{~km}$ further north, by the Kara Sea basin (Möller et al. 2007). There, stacked sequences of tills interbedded with marine sediments suggest that each Kara Sea ice-sheet cycle started with local warm-based glaciers spreading onto the Kara Sea shelf. But here they were later followed by cold-based thermal regimes over the "inception islands" (Bolšijanov 2006, as discussed below), rather than by an invasive Kara Sea ice sheet. These questions are further discussed by Möller et al. (2008) and Ingólfsson et al. (2008) in this issue.

Our inland inception pattern, at least spatially, resembles the concept of local ice caps on the Taymyr Peninsula and surrounding areas suggested by Bolšijanov (2006: fig. 38). However, these ice caps were considered to be "passive", i.e., cold-based, glacially non-erosive and leaving no glacial or glacifluvial deposits behind, only traces of fluvial erosion associated with their melting. Our documentation of warm-based, distinctly erosive and sediment-depositing glaciers originating in the Byrranga Mountains and surrounding hills therefore contradicts some of these ideas. However, the presence on Taymyr of cold-based, more or less "passive" local ice caps during the LGM, when ice-sheet glaciation this far east seems to have been very limited (e.g., Hjort et al. 2004; Svendsen et al. 2004), should not be excluded.

According to our data, the last "active" and large-scale glaciation of these parts of the Taymyr Peninsula seems to date from ca. 70 Kya or, according to the OSL age of the foreshore sediments associated with the marine limit, may be even older. Thus, the reconstruction of the Kara Sea ice sheet for our area around 60 Kya by Svendsen et al. (2004: fig. 15) now seems doubtful, and that depicted for 55-45 Kya by Larsen et al. (2006: fig. 10) is certainly invalid. Both these reconstructions indicated glaciation in the south-eastern Kara Sea basin. In that area, the last large-scale inland-derived glaciation dates from the Saale (MIS 6), and the last Kara Sea glaciation dates from the Early Weichselian (MIS 5 or 4); whereafter only local, cold-based ice caps may have existed.

\section{Acknowledgements}

QUEEN was a European Science Foundation project with strong economic support from the EU. The 2002 expedition to western Taymyr was logistically supported and organized by the Swedish Polar Research Secretariat, through a contract with INTAARI in St. Petersburg. The OSL dating of sediment samples was funded by the Danish Natural Science Research Council. Our glacial history work was carried out in parallell with the work of our Russian colleagues Grigorij Fedorov, from the Arctic and Antarctic Research Institute in St. Petersburg, and Andrey Onishev, from CAGRE in Norilsk, both of whom are thanked for their good company in the field. Kalle 
Ljung, at the Quaternary Science Department of Lund University, who produced the maps in Fig. 1, and Kurt Kjaer at the Geological Museum, University of Copenhagen, who drew the sediment log in Fig. 3, and helped with the other illustrations, are thanked for their help!

\section{References}

Agassiz L. 1840. Études sur les glaciers. (Studies of glaciers.) Neuchâtel: Jent \& Gassmann.

Alexanderson H., Adrielson A., Hjort C., Möller P., Antonov O., Eriksson S. \& Pavlov M. 2002. Depositional history of the North Taymyr ice-marginal zone, Siberia-a landsystem approach. Journal of Quaternary Science 17, 361-382.

Alexanderson H., Hjort C., Möller P., Antonov O. \& Pavlov M. 2001. The North Taymyr ice-marginal zone, Arctic Siberia-a preliminary overview and dating. Global and Planetary Change 31, 427-445.

Antonov O., Bolshiyanov D., Kulakov S. \& Burova Z. 2002. Quaternary deposits of the western Taymyr according to results of 2000-2001 field researches. Poster presented at the 6th QUEEN Workshop, Spiez, Switzerland, 24-28 May.

Astakhov V.I. 1976. Geologičeskie dokazatel'stva centra plejstocenovogo oledenenija na Karskom šel'fe. (Geological evidence of a centre of the Pleistocene glaciation on the Kara shelf.) Doklady Akademii Nauk SSSR 23, 1178-1181.

Astakhov V.I. \& Mangerud J. 2005. The age of the Karginsky interglacial strata on the lower Yenisei. Doklady Akademii Nauk, Earth Sciences 403, 673-676.

Astakhov V. \& Mangerud J. 2007. The geochronometric age of the Late Pleistocene terraces of the lower Yenisey. Doklady Academii Nauk, Earth Sciences 416, 509-513.

Bezzubcev V.V., Zaljaleev R. \& Sakovič A. 1986. Geologičeskaja karta Gornogo Tajmyra. Mašstab 1:500 000. Ob'jasnitel'naja zapiska. (Geological map of highland Taymyr. Scale 1 : 500000. Explanatory notes.) Krasnojarsk: Krasnojarskgeologija Surveying Facility, Ministry of Geology.

Bolšijanov D.Ju. 2006. Passivnoe oledenenie Arktiki i Antarktiki. (Passive glaciation of the Arctic and Antarctic.) St. Petersburg: Arctic \& Antarctic Research Institute.

Grosswald M.G. 1980. Late Weichselian ice sheet of northern Eurasia. Quaternary Research 13, 1-32.

Grosswald M.G. 1998. Late Weichselian ice sheets in Arctic and Pacific Siberia. Quaternary International 45/46, 3-18.

Hahne J. \& Melles M. 1997. Late- and post-glacial vegetation and climate history of the southwestern Taymyr Peninsula, central Siberia, as revealed by pollen analysis of a core from Lake Lama. Vegetation History and Archeobotany 6, 1-8.

Hjort C., Fedorov G., Funder S. \& Onishev A. 2003. Taymyr Quaternary geology 2002-the glaciers did not always come from the Kara Sea. Swedish Polar Research Secretariat Yearbook 2002, 80-84.

Hjort C., Möller P. \& Alexanderson H. 2004. Weichselian glaciation of the Taymyr Peninsula, Siberia. In J. Ehlers \& P.L. Gibbard (eds.): Quaternary glaciations-extent and chronology. Part 1. Europe. Pp. 10-16. Amsterdam: Elsevier.
Ingólfsson O., Lokrantz H. \& Möller P. 2008. Late Quaternary marine-based Kara Sea ice sheets: a review of terrestrial stratigraphic data highlighting their formation. Polar Research 27, 152-161 (this issue).

Isayeva L.L. 1984. Late Pleistocene glaciation of north-central Siberia. In A.A. Velichko (ed.): Late Quaternary environments of the Soviet Union. Pp. 21-30. Minneapolis: University of Minnesota Press.

Kind N.V. \& Leonov B.N. (eds.) 1982. Antropogen Taymyra. (The Antropogene of the Taymyr Peninsula.) Moscow: Nauka.

Larsen E., Kjaer K.H., Demidov I.N., Funder S., Grösfjeld K., Houmark-Nielsen M., Jensen M., Linge H. \& Lyså A. 2006. Late Pleistocene glacial and lake history of northwestern Russia. Boreas 35, 394-424.

Malič N. (ed.) 1999. Geologičeskaja karta Sibirskoj platformy $i$ prilegajušcih territorij. (Geological map of the Siberian platform and adjoining areas.) $1: 1500$ 000. St. Petersburg: A.P. Karpinsky All-Russian Institute of Geological Research.

Möller P., Bolshiyanov D.Y. \& Bergsten H. 1999. Weichselian geology and paleoenvironmental history of the central Taymyr Peninsula, Siberia, indicating no glaciation during the last global glacial maximum. Boreas 28, 92-114.

Möller P., Fedorov G., Pavlov M., Seidenkrantz M.-S. \& Sparrenbom, C. 2008. Glacial and paleoenvironmental history of the Cape Chelyuskin area, Arctic Russia. Polar Research 27, 222-248 (this issue).

Möller P., Lubinski D.J., Ingólfsson Ó., Forman S.L., Seidenkrantz M.-S., Bolshiyanov D.Y., Lokrantz H., Antonov O., Pavlov M., Ljung K., Zeeberg J. \& Andreev A. 2007. Severnaja Zemlja, Arctic Russia: a nucleation area for Kara Sea ice sheets during the Middle to Late Quaternary. Quaternary Science Reviews 25 , 2894-2936.

Murray A.S. \& Funder S. 2003. Optically stimulated luminescence dating of a Danish Eemian coastal marine deposit: a test of accuracy. Quaternary Science Reviews 22, 1177-1183.

Obruchev W.A. 1930. Die Verbreitung der Eiszeitspuren in Nord- und Zentralasien. (Traces of the ice age in northern and central Asia.) Geologische Rundschau 21, 242-283.

Pease V. \& Persson S. 2006. Neoproterozoic island arch magmatism of northern Taimyr. In R. Scott $\delta$ D. Thurston (eds.): Proceedings of the Fourth International Conference on Arctic Margins. Pp. 31-49. Anchorage, AK: Minerals Management Service, US Dept. of the Interior.

Saks V.N. 1953. Četvertičnyj period v Sovetskoj Arktike. (The Quaternary period in the Soviet Arctic.) Leningrad: Vodtransizdat.

Svendsen J.I., Alexanderson H., Astakhov V.I., Demidov I., Dowdeswell J.A., Funder S., Gataullin V., Henriksen M., Hjort C., Houmark-Nielsen M., Hubberten H.W., Ingólfsson Ó., Jakobsson M., Kjaer K.H., Larsen E., Lokrantz H., Lunkka J.P., Lyså A., Mangerud J., Matiouchkov A., Murray A., Möller P., Niessen F., Nikolskaya O., Polyak L., Saarnisto M., Siegert C., Siegert M.J., Spielhagen R.F. \& Stein R. 2004. Late Quaternary ice sheet history of northern Eurasia. Quaternary Science Reviews 23, 1229-1271. 
Strelkov S.A. 1965. Sever Sibiri. (The Siberian north.) Moscow: Nauka.

Thomas P.J., Murray A.S., Kjaer K.H., Funder S. \& Larsen E. 2006. Optically stimulated luminescence (OSL) dating of glacial sediments from Arctic Russia-depositional bleaching and methodological aspects. Boreas 35, 587-599. Urvantsev N.N. 1931. Četvertičnoe oledenenie Tajmyra. (Quaternary glaciation of Taymyr.) Bulleten' Komissii po Izučeniju Četvertičnogo Perioda 3, 23-42.
Urvantsev N.N. 1935. Drevnee oledenenie na severa SSSR. (Ancient glaciation in the north of the USSR.) In: U.S.S.R. Glavnoe upravlenie Severnogo morskogo puti. Geologo-razvedočnaja konferencija 1st, Moskva, 1935. Geologija $i$ poleznye iskopaemya Severa SSSR. Trudy. T. 1. Geologija.

(Former USSR chief administration of the northern marine route. 1st geological exploration conference, Moscow, 1935. Geology and minerals of the USSR north. Proceedings. Vol. 1. Geology.)

Pp. 129-148. Leningrad. 